\title{
Chronicity, self care, social and family support: how the patient has?
}

\author{
Francisca Alexandra Araújo da Silva*, Thereza Maria Magalhães Moreira, Luciana Gomes Catunda Menezes \\ From 20th Brazilian Diabetes Society Congress \\ Porto Alegre, Brazil. 11-18 November 2015
}

\section{Background}

Diabetes mellitus is a non-communicable chronic systemic disease. It is estimated that in 2030 will have over 300 million diabetics worldwide. Perform preventive measures on the glycemic control, foot care and other education initiatives in diabetes favors the reduction of signs and symptoms of the disease progression.

\section{Objective}

This study aimed to evaluate sociodemographic and clinical characteristics of a group of diabetics as well as meet social relations that permeate the self-care of these patients.

\section{Materials and methods}

Cross-sectional study, epidemiological performed in a referral center for diabetes and hypertension the northeast region of Brazil in the period June to August 2013.

\section{Results}

A total of 538 people with diabetes, and the study population was predominantly female (63 4\%), married people or with fixed partners (55.6\%), older (59.7\%), Catholic (72.1\%), low education, less than 10 yrs. (74\%); 65\% with incomes below twice the minimum wage. On clinical data $79.2 \%$ were hypertensive, $69.1 \%$ with over 10 yrs. of diagnosis of diabetes mellitus, $40.7 \%$ used medication by mouth for diabetes control, when asked about the help or assistance of others towards treatment, $62.3 \%$ reported not having social or family support or even encouragement to move with adherence to medication or non-medication treatment for diabetes. When asked about following the prescribed diet, only $60.4 \%$ reported following the diet routinely, as physical activity, $61.2 \%$ of persons were sedentary, $72.7 \%$ presented themselves with excess weight, and those with overweight or obese, $63.6 \%$ of diabetic

\footnotetext{
* Correspondence: falexandraaraujos@yahoo.com.br Universidade Estadual do Ceará, Fortaleza, Brazil
}

people found themselves with altered glycemia, with greater $140 \mathrm{mg} / \mathrm{dL}$ at the time of data collection at random.

\section{Conclusion}

Notoriously we see, when we analyze the data, the chronicity characteristics of the disease, lack of social and family support to these patients, worsening of clinical status and poor adherence to self-care of the person with Diabetes Mellitus. It is extremely important that multidisciplinary actions aimed at intensive care to this population are

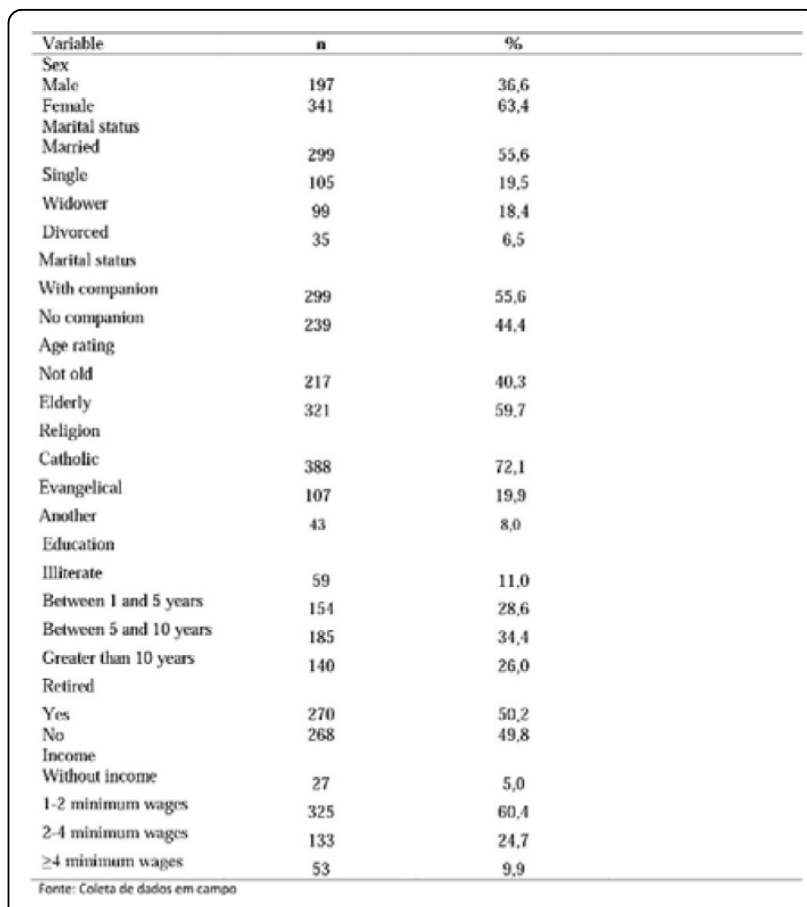

Figure 1 Socio-demographic characteristics of people with diabetes mellitus treated as a referral center in a Northeastern capital. 2015. 


\begin{tabular}{|c|c|c|}
\hline Varisble & $\mathrm{N}$ & $\%$ \\
\hline \multicolumn{3}{|l|}{ Hypertension } \\
\hline Yes & 426 & 79.2 \\
\hline No & 112 & 20.8 \\
\hline \multicolumn{3}{|l|}{ Diabetes mellitus time } \\
\hline$\leq 10$ years & 166 & 30.9 \\
\hline$\geq 10$ years & 372 & 69.1 \\
\hline \multicolumn{3}{|l|}{ Treatmeat } \\
\hline Oral & 219 & 40.7 \\
\hline Injectable & 103 & 19.1 \\
\hline Conjugate & 213 & 39.6 \\
\hline \multicolumn{3}{|l|}{ Aswivance for the Treatment } \\
\hline Wife & 70 & 13.0 \\
\hline Children & 102 & 19,0 \\
\hline Friends & 2 & $A$ \\
\hline Oltors & 29 & 5,4 \\
\hline Nubody & 335 & 62,3 \\
\hline \multicolumn{3}{|l|}{ Follow the prescribed dies } \\
\hline Yos & 325 & 60.4 \\
\hline No & 213 & 39.6 \\
\hline \multicolumn{3}{|l|}{ Miycial activility } \\
\hline Yes & 209 & 38,8 \\
\hline No & 329 & 61.2 \\
\hline \multicolumn{3}{|l|}{ Exeess weight } \\
\hline No & 147 & 27.3 \\
\hline Yes & 391 & 72,7 \\
\hline \multicolumn{3}{|l|}{ Clycemis } \\
\hline Less than $140 \mathrm{mg} / \mathrm{dl}$ & 196 & 36.4 \\
\hline Gerester than ex equal to $140 \mathrm{mg} / \mathrm{dl}$ & 342 & 63.6 \\
\hline
\end{tabular}

drawn at national level through effective public health policies they can minimize grievances as well, decrease complications using lines of care in diabetes care and management.

Published: 11 November 2015

doi:10.1186/1758-5996-7-S1-A202

Cite this article as: da Silva et al: Chronicity, self care, social and family support: how the patient has? Diabetology \& Metabolic Syndrome 20157 (Suppl 1):A202.
Submit your next manuscript to BioMed Central and take full advantage of:

- Convenient online submission

- Thorough peer review

- No space constraints or color figure charges

- Immediate publication on acceptance

- Inclusion in PubMed, CAS, Scopus and Google Scholar

- Research which is freely available for redistribution

Submit your manuscript at www.biomedcentral.com/submit 